\title{
Systemic and local hormonal requirements for implantation in domestic animals*
}

\author{
B. Cook $\uparrow$ and R. H .F. Hunter $\ddagger$ \\ †Department of Steroid Biochemistry, University of Glasgow, Royal Infirmary, \\ Glasgow G4 OSF, and \\ $\ddagger$ School of Agriculture, University of Edinburgh, West Mains Road, \\ Edinburgh EH9 3JG, U.K.
}

Implantation and some related events in domestic animals

Association of the embryo with the uterine epithelium, by either superficial attachment or specific embedding in or beneath the endometrium, leads in due course to the formation of a placenta and complete dependence of the differentiating embryo upon metabolic support from the mother. The time of implantation after fertilization varies widely amongst the common domestic animals and so, therefore, do the stage and size of embryonic development at the initiation of a functional contact with the uterine tissues (Wimsatt, 1975). Delayed implantation of the blastocyst-the period of embryonic diapause found in certain species of deer, carnivore and rodents during seasonal or lactational anoestrus-has not been documented as a feature of reproduction in domestic cattle, sheep or pigs. Before considering endocrine aspects of the implantation process, it seems necessary to comment upon some of the significant stages preceding this critical phase of development. More extensive treatments of the topic can be found in the reviews of Blandau (1971), Finn (1971), McLaren (1972) and Psychoyos (1973), although rodents rather than the larger domestic species are the principal concern of such works.

Embryos enter the uterus from the Fallopian tubes about 2 days after fertilization in the pig (Assheton, 1898; Heuser \& Streeter, 1929), approximately 1 day later in the sheep and cow, but not until 5-7 days after fertilization in the horse (Thibault, 1972). Unfertilized horse eggs remain in the Fallopian tubes where they undergo extensive cytoplasmic degeneration (van Niekerk \& Gerneke, 1966). This precocious transport of the pig embryo into the uterus compared with the timing in sheep and cows is also reflected in subsequent events such as emergence from the zona pellucida (hatching), the expansion of the blastocyst, and the start of a specific morphological interaction between the trophoblast and endometrium that varies in time from about 2 weeks in the pig up to as late as 5 weeks after fertilization in cattle.

The rate of passage of embryos along the oviducts into the uterus is principally under the control of ovarian steroid hormones, and the timing of entry into the uterus has been shown to be critical if embryonic development and a successful pregnancy are to ensue. This has been established experimentally by the twin approaches of disturbing the normal rate of tubal transport by treatment with gonadal steroids (Burdick \& Pincus, 1935; Greenwald, 1959; Chang, 1966) and by the more elegant procedure of embryo transplantation (Chang, 1950; Noyes \& Dickmann, 1960; Rowson \& Moor, 1966a). The latter approach has demonstrated that the stage of embryonic development needs to be closely synchronized with that of the hormonally regulated endometrial proliferation if a high incidence of pregnancy is to result; an exception, perhaps, is found in primates (see Hunter, 1977a). Among the larger domestic species with their longer oestrous cycles and gestation periods, there appears to be some tolerance in the synchronization requirements: although the highest conception rates following transplantation have usually been recorded when synchronization has been precise, Rowson and his colleagues have shown that cow and sheep embryos can tolerate an asynchrony with the stage of uterine development of \pm 1 and \pm 2 days, respectively (Rowson \& Moor, 1966a; Rowson, Moor \& Lawson, 1969; Rowson, 1971).

* Dedicated to Andy Nalbandov on his retirement from the Faculty of the University of Illinois, after 37 years of stimulating teaching and research. 
There are a number of features common to the preimplantation embryos of cattle, sheep and pigs. First, as appears to be the case for a variety of ungulates, these three species all show a remarkable expansion of the blastocyst by extensive proliferation of the trophoblast shortly after hatching from the zona pellucida. This proliferation is accompanied by a morphological transition from a spherical, fluid-filled blastocyst to a much extended conceptus in cow (Winters, Green \& Comstock, 1942; Chang, 1952) and sheep (Green \& Winters, 1945; Rowson \& Moor, 1966b) or to an extremely long thread-like conceptus in pig (Heuser \& Streeter, 1929; Green \& Winters, 1946; Perry \& Rowlands, 1962).

Second, cow, sheep and pig embryos all undergo a prolonged free-living stage in the uterine lumen before beginning to implant (attach), and the alteration in size and shape of the embryo may well be associated in part with the means of metabolic support by constituents of the uterine fluid (histotrophe); these secretions are known to be closely regulated by the prevailing balance of oestrogens and progesterone (see below). This long free-living stage permits a wider use of the technique of transplantation than is possible in rodents, because conceptuses aged up to 13 days in the sheep (Moor \& Rowson, 1964) or 16 days in cattle (Betteridge, 1977) can be flushed from the uterus of donor animals and transplanted successfully to the uterus of recipients. Moreover, the advanced stage of development attained by the free-living embryo is exploited during transplantation; embryos can be subjected to microscopic examination between recovery and transfer and by imposing a morphological selection at this stage (i.e. by not transplanting embryos that, for example, appear retarded or show signs of fragmentation) the conception rate after transplantation may be elevated (see Hunter, 1976).

Third, and in contrast to the situation in many species of laboratory rodent and primates, implantation in cattle, sheep and pigs is both central and essentially superficial, the placenta that is subsequently formed being of the epithelio-chorial (pig) or syndesmo-chorial (cow and sheep) type with the conceptus remaining in the uterine lumen (Wimsatt, 1975). Bearing in mind the preceding remarks concerning expansion of the trophoblast and the long free-living stage, it is scarcely surprising that the embryo does not invade deeply into the maternal tissues or initiate a decidual cell reaction of the type characteristic of rodents. On these grounds, therefore, quite apart from other reasons, it is clear that the use of the term 'nidation' as a synonym for implantation is inappropriate for the domestic urgulates; the word 'attachment' would seem more descriptive.

Fourth, during the free-living stage, a redistribution of embryos between the horns of the bicornuate pig uterus or bipartite ruminant uterus may occur, this phenomenon being traditionally referred to as intrauterine migration of the embryo (Corner, 1921; Warwick, 1926; Dziuk, Polge \& Rowson, 1964). Whilst such migration has been noted at only a low incidence in cattle and sheep, intrauterine migration and mixing of embryos is an invariable feature of reproduction in the domestic pig. Indeed, if it were not found in this polyovular species in which disparity in the number of eggs released between the two ovaries is the rule and not the exception, competition between embryos would undoubtedly elevate the already significant level $(25-40 \%)$ of prenatal mortality. In a recent review of reproduction in the pig, it has been argued that intrauterine migration should more correctly be viewed as a redistribution rather than migration, since the embryos are probably passive in the overall physical sense, although their biosynthetic activity in the form of oestrogen and/or prostaglandin secretion (see below) may contribute to a local enhancement of myometrial contractions (Hunter, 1977b).

Concerning actual implantation, the beginning of a tenuous attachment to the endometrium is seen in Day-13 pig embryos in the form of short microvilli extending from the surface of the trophoblast, microvilli also becoming a feature of the endometrial surface at this time (Crombie, 1970). Even though contact between maternal and embryonic surfaces remains diffuse, attachment of the pig embryo is well advanced by Day 18, whereas in the sheep the more specialized caruncular regions show the earliest morphological signs of attachment on about Day 15 (Boshier, 1969) when the conceptus may measure up to 15-19 cm in length (Chang \& Rowson, 1965; Rowson \& Moor, 1966b). In pigs and sheep, the timing of initial attachment is such that the activity of the corpus luteum could be influenced by this event. By contrast, morphological evidence indicates that attachment in the cow does not begin until after Day 30 , when chorionic (trophoblastic) villi make specific contact with 
maternal tissues in the crypts of the caruncles and eventually form the functional unit of the placentome. Trophoblastic activity may also influence other areas of the uterine epithelium in ruminants by invasion and destruction.

The attachment relationship of the horse embryo is less intimate than that of ruminants, the conceptus remaining essentially free in the lumen for more than 1 month, although it is in contact with the uterine epithelium because it has swollen by fluid accumulation. By Day 37, however, an intimate attachment develops between the cells of the chorionic girdle and the underlying endometrial epithelium (Moor, Allen \& Hamilton, 1975), and by Day 45 rudimentary villi occur over the entire surface of the allanto-chorion and interdigitate with the maternal crypts (van Niekerk \& Allen, 1975).

For the embryo to survive and mature into a fetus in these domestic species, three major processes, undoubtedly influenced by hormones, have to proceed. First, regression of the corpus luteum must be prevented; second, in polytocous animals, appropriate spacing of the embryos must be ensured; and third, uterine formation of histotrophe has to occur.

\section{Luteotrophic actions of the blastocyst}

Because attachment of the blastocyst is relatively late in domestic animals (see above), the signal initiating maintenance of the corpus luteum may have to be given while the embryo is free in the uterus. This is true regardless of whether the embryo is involved in initiating production of a luteotrophin or suppressing the action of a luteolysin. Protein hormone production by blastocysts is well known in women in whom hCG has been detected in peripheral plasma as early as 6 days after conception (Saxena, Hasan, Haour \& Schmidt-Gollwitzer, 1974). This hormone is therefore produced in ample time for it to exert a luteotrophic action. Among the domestic species, by contrast, an embryonic gonadotrophin has been detected only in the mare. Endometrial cups, structures derived from embryonic tissues, develop from about Day 36 and produce serum gonadotrophin (PMSG) (Allen \& Moor, 1972). This is clearly too late for PMSG to act as a luteotrophin in prolonging the lifespan of the cyclic corpus luteum, but the possibility of an earlier production of a PMSG-like compound by embryonic tissues cannot be excluded. The signal for the maintenance of the corpus luteum in the mare is given on or before Day 16 (van Niekerk, Morgenthal \& Gerneke, 1975); therefore examination of blastocysts for their ability to produce a gonadotrophin should be undertaken at this time.

In sheep and cows, evidence for the production of gonadotrophin-like hormones by blastocysts near the time of implantation is weak. In these species, oestrogen, which has been reported to be luteolytic in the late luteal phase, may act indirectly to induce synthesis of prostaglandin (PG) F-2 $\alpha$ at uterine (Goding, 1974) or ovarian (Cook, Karsch, Foster \& Nalbandov, 1974) sites. The role of an embryonic gonadotrophic hormone could be to counter the lytic action of PGF-2 $\alpha$. Continuous systemic infusion of LH into intact cyclic sheep has been shown to prevent luteolysis (Karsch et al., 1971), but increased plasma concentrations of LH during the period of maternal recognition of pregnancy in ewes were not demonstrated by Niswender, Roche, Foster \& Midgley (1968), who used a radioimmunoassay to make their measurements. A more definitive result could now be given by a radioreceptor assay because proteins producing similar biological responses (such as a putative embryonic gonadotrophin and $\mathrm{LH}$ ) need not have similar structures, except, perhaps, at the active centre, and antibodies are not necessarily directed against this unique region which reacts with a receptor in or on the target cell.

Embryos may have the capacity to synthesize steroid as well as protein hormones. The first demonstration of steroidogenic activity by developing blastocysts was reported for rabbits by Huff \& Eik-Nes (1966). More recently, preimplantation pig embryos have been shown to be particularly active in oestrogen biosynthesis (Perry, Heap, Burton \& Gadsby, 1976; Heap et al., 1977): oestrogen is produced by trophoblastic tissue by Day 12-early enough for this steroid to be involved in the signal for luteal maintenance. Oestrone appears to be sulphated by the endometrium, but the probable target tissues (hypothalamus, pituitary and corpus luteum) all have active sulphatases which

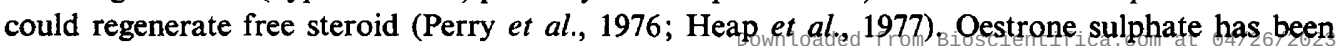


detected in the peripheral plasma of pregnant pigs from Day 17 after oestrus but was not found in cyclic pigs at this time (Robertson, King \& Dyck, 1978). Oestrogens have been shown to be luteotrophic in the intact unmated pig; daily administration started on Day 11 maintained functional corpora lutea to slaughter on Day 33 (Gardner, First \& Casida, 1963).

Oestrogens are generally supposed to elicit a positive feedback response from the hypothalamus and pituitary to stimulate gonadotrophin release, since LH is luteotrophic in pigs from Day 14 onwards (du Mesnil du Buisson \& Denamur, 1968). Furthermore, Chakraborty, England \& Stormshak (1972) showed that injections of oestradiol into gilts from Days 11 to 16 of the cycle increased pituitary weight and FSH and LH activity above control values at autopsy on Day 17. These workers also showed that ovarian follicular growth was inhibited and luteal progesterone concentration was increased, but they interpreted these changes as a secondary response to the altered pituitary function. On the other hand, oestrogens have been demonstrated to elicit a direct stimulation of steroidogenesis in porcine ovarian preparations in vitro. Goldenberg, Bridson \& Kohler (1972) showed that oestrogen stimulated progesterone synthesis in cultures of granulosa cells harvested from antral follicles. By contrast, Cook, Niswender, Sutterlin, Norton \& Nalbandov (1968) did not, in general, enhance progesterone biosynthesis by luteal slices in an incubation system with oestrogens, but in one experiment with corpora lutea obtained on Day 10 of the cycle, oestradiol gave a dose-related increase in progesterone accumulation. Heap et al. (1977) reported that synthesis of oestrogen by blastocysts started between Days 10 and 12, immediately preceding the time of maternal recognition of pregnancy in pigs. If direct stimulation of luteal progesterone synthesis by oestrogens is part of the humoral system through which the embryo signals its presence, Cook et al. (1968) might have harvested corpora lutea before they were uniformly sensitive to the dose of oestrogens employed.

Target tissues contain receptors for their agonists and oestrogen receptors exist in corpora lutea from rabbits, another species in which oestrogen is luteotrophic (Lee, Keyes \& Jacobson, 1971; Scott \& Rennie, 1971). Similar receptors have been demonstrated in corpora lutea from cows (Kimball \& Hansel, 1974) and sheep (Cook \& Taylor, 1974), but oestrogen generally acts in a luteolytic manner in these two species of ruminant late in the cycle. Heap et al. (1977) reported preliminary evidence for the presence of 'oestrogen receptors' in pig corpora lutea and we have shown that porcine luteal cytosol has oestrogen binding capacity, although few studies of the specificity of this binding have been completed (B. Cook, unpublished observations). There is, therefore, good circumstantial evidence that oestrogen biosynthesis by the expanded pig blastocyst might indicate the presence of a gravid uterus. The biochemical components necessary for oestrogen to act directly on the corpus luteum may be present, but a systemic effect mediated through the pituitary gland is also possible.

The presence of dehydrogenases that could facilitate steroid hormone biosynthesis has been demonstrated histologically in embryonic tissues of the mare (Flood \& Marrable, 1975). The evidence for steroidogenesis by sheep and cow blastocysts is weaker than that for pigs, but Gadsby, Burton, Heap \& Perry (1976) have claimed that steroidogenesis occurs both "before and after attachment". The main products in these species appear to be neutral steroids; oestrogen production by blastocysts appears to be low or absent. Ayalon and his colleagues, who have studied steroid production by bovine blastocysts, agree with these preliminary findings (N. Ayalon, personal communication). These steroids could still serve as signals to the mother of the presence of a uterine embryo; they could, for instance, act centrally as pre-hormones (Martensz, Baird, Scaramuzzi \& Van Look, 1976) to be aromatized in the brain to yield oestrogens which, in turn, would modulate LH production (Naftolin et al., 1975). They might also act locally on the corpus luteum to inhibit the luteolytic action of PGF-2 $\alpha$. Specific receptors for corticosteroids have been characterized in cytosol from rabbit corpora lutea (B. Cook, R. A. Cowan, S. K. Cowan \& A. S. L. Kelly, unpublished), and such receptors could exist in luteal cells from other species. The function of these receptors is quite unknown, but a role for them in luteal maintenance should not be discounted (see later).

So far, the embryo has been considered as a possible source of steroids and gonadotrophins. Production of prolactin-like hormones also occurs; formation of a placental lactogen is well documented in women (Singer, Desjardins \& Friesen, 1970) and analogous compounds have been reported in goats (Buttle, Forsyth \& Knaggs, 1972) and sheep and cows (Chan, Robertson \& Friesen, 1976). Chan et al. (1976) have purified and partly characterized ovine placental lactogen which they found 
to have structural features in common with human growth hormone. Martal \& Djiane (1977) have demonstrated the presence of chorionic somatomammotrophin ( $\equiv$ placental lactogen) in sheep trophoblasts from Days 16-17 of pregnancy onwards: placental concentrations of this hormone rise slowly up to Day 100, and then the increase becomes more rapid. Rowson \& Moor (1967) reported that the embryo of the sheep contained material that was able to prevent regression of the cyclic corpus luteum: homogenates of 14 - and 15 -day-old embryos, stored at $-20^{\circ} \mathrm{C}$, and infused daily into uteri from Day 12 of the cycle, could maintain cyclic corpora lutea to at least Day 23. This material was heat-labile, species-specific and absent from Day-25 embryos. Martal \& Djiane (1977) cite two reasons why they do not believe that placental lactogen is the material detected in embryonic homogenates by Rowson \& Moor (1967). First, ovine chorionic somatomammotrophin was not detected before Day 16, which is too late for this material to elicit maintenance of the cyclic corpus luteum, and second, uterine infusion of purified ovine placental lactogen $(40 \mu \mathrm{g} /$ prolactin equivalents/day) into cyclic ewes starting on Day 12 did not give luteal maintenance. No details were given of this last experiment, which was mentioned only in passing and was, presumably, a preliminary observation (Martal \& Djiane, 1977). There are several reasons for keeping an open mind on the matter at present; the fact that chorionic somatomammotrophin was not detected in ovine blastocysts before Day 16 does not mean that its synthesis was not occurring. A culture system in which the protein could accumulate would be more useful as a means of assessing synthesis. Further work is also needed to clarify the in-vivo perfusion study of Martal \& Djiane (1977); a range of doses of placental lactogen and perhaps different infusion routes need to be tested. The neutral steroids (see p. 474) could also be an essential part of a luteotrophic complex. An exhaustive evaluation of the role of chorionic somatomammotrophin in luteal maintenance in sheep would be profitable. Denamur, Martinet \& Short (1973) have reported that prolactin is luteotrophic in sheep and is part of the accepted luteotrophic complex in this species. Furthermore, in women, hyperprolactinaemia leads to inhibition of follicular maturation (McNatty, Sawers \& McNeilly 1974). Because luteolysis appears to be induced by PGF- $2 \alpha$ in sheep and PGF- $2 \alpha$ production appears to be oestrogen dependent, a block on follicular development or maturation and hence in oestrogen production could underlie luteal maintenance. Thus, if prolactin acted in sheep in a manner similar to that reported in women, it could suppress the luteolysin. A second possibility would be a direct trophic effect on corpora lutea comparable to that reported in rodents (Armstrong, 1968) (see also p. 477).

Work by Richards \& Midgley (1976) and Richards \& Williams (1976) on follicular development and luteal function suggests how some of these observations and hypotheses might fit together. It was concluded from their work in rats that pituitary hormones induce the maturation (i.e. availability) of receptors for themselves and for gonadal hormones in ovarian tissues. More specifically, oestradiol increases oestradiol receptors in granulosa cells, FSH increases FSH receptors, and FSH and oestradiol together increase $\mathrm{LH}$ receptors. Thus, oestrogen may act luteotrophically in porcine luteal cells by inducing LH receptors (see Hunter, Cook \& Baker, 1976). The cells could then continue to bind LH, which would stimulate progesterone production through the accepted sequence of events (Marsh, 1976). Richards and her colleagues have also shown that luteinization in rats is associated with the loss of FSH receptors and a decrease in receptors for oestradiol and LH. Prolactin receptors increase, and progesterone production occurs only if sufficient prolactin is present during critical periods. In the presence of prolactin, $\mathrm{LH}$ receptors and progesterone production both increase, though the relationship of these events to one another is undefined. At different stages of luteinization, therefore, changes in oestradiol and prolactin availability are associated with changes in $\mathbf{L H}$ receptor content. Blastocysts in different species therefore appear to have the ability to influence the availability of gonadotrophic, lactogenic or gonadal hormones.

\section{Uterine spacing of blastocysts}

Among the species of farm livestock, the pig is the only one that is always polytocous. It can have a disparity of as much as $1: 15$ in the number of ovulations from the two ovaries, although successful and biologically efficient reproduction requires that the difference between the number of embryos 
developing in each uterine horn should be minimized. Redistribution of embryos between the two horns of the pig uterus occurs principally during the 9th to 11 th days of embryonic life (Dhindsa, Dziuk \& Norton, 1967; Polge \& Dziuk, 1970), such that an even spacing of embryos is achieved by the time implantation is initiated on Day 13. The method of displacement of the embryos is not known. Böving (1971) reported that the propulsive force for the movement of blastocysts in rabbits was derived from myometrial contractions, and oestrogens have been reported to stimulate such contractions in this and other species. Rabbit blastocysts contain some of the enzymes necessary for oestrogen production (Dickmann, Dey \& Sen Gupta, 1976), although conclusive demonstration of oestrogen production by these tissues is still lacking (Bullock, 1977a). Lengthwise movement in both directions is possible; in rabbits, contraction waves stimulated by an object that distends the uterus travel outwards in both directions along the horn. While these waves do not move the object itself, they do propel its neighbours in opposite directions. In the pig, the production of oestrogens by the elongating blastocyst could presumably trigger and sustain such a contractile pattern to give uniform spacing of embryos (see Hunter, 1977b), but direct experiments to test such a mechanism are lacking in this species.

In sheep with a single ovulation, intrauterine migration of the embryo rarely occurs although, of course, the placental membranes may extend around the septum and body of the uterus as gestation progresses. Reimers et al. (1973) showed that in 1030 pregnant ewes with a single corpus luteum, the embryo remained in the ipsilateral horn in more than $93 \%$ of the animals; only 38 embryos had been displaced into the contralateral horn. In 31 of 32 ewes, which had two corpora lutea in the same ovary, and in which twins were being carried, one embryo had always migrated to the contralateral horn. Similar results have been reported for cows (Scanlon, 1972). These findings would agree with Böving's (1971) proposition that embryos cause their neighbours and not themselves to be displaced.

Various PGs have been isolated from uterine fluid, and these compounds could also influence uterine motility at the time of intrauterine spacing of embryos (Bergström, 1967). In sheep, PGs are apparently secreted into the lumen by uterine tissues, probably the caruncles, and they are found in the absence of an embryo (Harrison, Heap, Horton \& Poyser, 1972). Prostaglandin production in ovariectomized ewes is enhanced by progesterone administration and not by oestradiol (Louis, Parry, Robinson, Thorburn \& Challis, 1977), although oestradiol does stimulate PG production in progesterone-primed animals. Bovine blastocysts, collected 13 days after insemination have also been shown to produce appreciable quantities of PGE and PGF in a culture system (N. Ayalon, personal communication), as can porcine embryos between 16 and 20 days of age (F. Maule-Walker, personal communication). Whether such embryonic secretions influence uterine motility or whether they have some other role involving the relationship between embryo, uterus and ovaries remains to be investigated.

\section{Uterine-specific proteins}

The importance of synchrony of development between the blastocyst and uterus was noted earlier in this paper. An underlying reason for this requirement is that the embryo needs to derive nutrients from the uterine secretion and, at least in the early stages of development before the luteotrophic signal has been given, this secretion will be controlled by ovarian hormones. Therefore the uterus, under the control of maternal hormones, must secrete substances, possibly as simple as Krebs' cycle intermediates, that the embryonic membranes can absorb and utilize. Unfortunately, little is known of the control of the secretion of such energy substrates of low molecular weight. On the other hand, uterine- or pregnancy-specific proteins have been studied in a number of species. Perhaps the best known is uteroglobin or blastokinin which is produced in the rabbit uterus. Many aspects of the biology of this compound have been reviewed (Beier, 1974, 1976; Bullock, Woo \& O'Malley, 1976; Daniel, 1976; Beato, 1977). The relevance of this protein to reproductive events is obscure, for although its secretion in the uterus is regulated by progesterone and although it binds progesterone with moderate affinity, proteins closely similar to uteroglobin are found in other organs, such as the lung, where their biosynthesis appears to be independent of endocrine control (Bullock, 1977b). 
Among the domestic species, uterine- or pregnancy-specific proteins have been studied most in pigs and cows. Bazer (1975) has reviewed the work of his group on the 'purple protein' found in pigs; this purple, basic, progesterone-induced glycoprotein (molecular weight $32000 \pm 3000$ ) with acid phosphatase activity, was obtained from uterine flushings from intact, non-pregnant gilts on Day 15 of the oestrous cycle. A protein with identical physical and chemical properties was also isolated from allantoic fluid collected between 30 and 100 days of gestation. The protein is maternal in origin, secreted by the endometrial surface and the glandular epithelium, absorbed through the placental areolae (regions apposed to the uterine glands), transported across the placental membranes and retained in the allantoic fluid. When antibodies were raised against purple protein and gilts were passively immunized, the effects seemed to be mainly on the placentae and not the fetuses. When antiserum raised in sheep was administered early in gestation, up to Day 15, and gilts were hysterectomized on Day 30, placental length and allantoic protein concentration were significantly reduced compared with the values in control animals receiving normal sheep serum. Wet and dry weight and crown-rump length of fetuses and placental wet weight were not changed. Antiserum administered later in pregnancy, from Days 34 to 42 , the period during which purple protein accumulation in allantoic fluid begins, resulted in placentae and fetuses which were smaller at Day 50 than those in control animals. Conversely, when oestrogen and progesterone were injected into gilts, uterine secretory activity was increased, and in pregnant gilts uteri were heavier, placentae were longer and allantoic fluid volume was greater than those of controls. Litter size and weight of embryos were not changed. Uterine secretion appears to enhance placental development in pigs. There is also evidence, cited by Bazer (1975), that progesterone-binding proteins exist in the uterine lumen in sows, cows and mares. These proteins may deliver progesterone to the blastocyst for further metabolic transformation and this function could be particularly important before attachment. Once intimate connections have been established between uterus and embryo, steroids from the maternal circulation could be transferred by mechanisms not available to the blastocyst during its free-living stage. It is of interest that a carrier protein, androgen-binding protein, appears to be involved in the transport of androgens to cells within testicular tubules which are also remote from a direct blood supply (Hansson et al., 1975).

Roberts \& Parker (1974) have detected small quantities of uterine-specific proteins in luminal fluid from bovine uteri and Laster (1977) has described a protein that can be detected in the uterus of cows 15 days after mating only when blastocysts are present. At Day 15, this protein represents about $1 \%$ of the total protein in endometrium and uterine flushings. This material has been physically characterized by several techniques, but no biochemical function or biological activity has been ascribed to it at present, and its precise site of synthesis and mode of induction also remain unknown. Cerini, Findlay \& Lawson (1976) and Cerini, Cerini, Findlay \& Lawson (1976) have described pregnancy-specific antigens in sheep which have a molecular weight in excess of 8000 and which contain both protein and carbohydrate components. This material was detected in embryos, myometrium, maternal blood and corpora lutea as early as 8 days after oestrus, but it was not detectable in endometrium and some other tissues. Its source and function remain unknown, but Cerini and her colleagues postulate that it is involved in the maternal recognition of pregnancy. The biochemical reasons underlying the need for synchrony between embryo and uterus in domestic animals therefore remain undefined. Nevertheless, present knowledge suggests that maternal progesterone is the key hormone involved in inducing the synthesis of components of uterine secretion.

A major problem in the study of uterine secretion is the correlation between structure and function of the molecules it contains. Laster (1977) suggests no biological activity for the compound he describes; the purple protein studied by Bazer et al. (1975) is an acid phosphatase, but the physiological role of such an enzyme in uterine secretion is not established; and uteroglobin, the predominant protein in rabbit uterine flushings, is still of obscure function (Beier, 1976), although its existence has been known for more than 10 years.

Apart from that of simple nutritional function, a role for uterine proteins that appears to have been overlooked so far concerns the provision of a means of maintenance of the structural integrity of the trophoblast during the phase of rapid expansion of the embryonic membranes. In the absence of a sufficiently rapid accumulation of fluid in the blastocoele, a massive and detrimental collapse of 
the trophoblast would occur. Uterine proteins might contribute significantly in making available a substance that would modify surface tension effects in these early stages of gestation. Although in no way analogous, the role of a protein molecule in maintaining the surface integrity of membranes is illustrated by the appearance of surfactant in fetal lung (Reynolds, 1973; Pattle, 1975): absence of this material in the fetal alveolae shortly before birth is invariably fatal.

\section{Other uterine components}

Lutwak-Mann \& McIntosh (1969) and McIntosh \& Lutwak-Mann (1972) reported that zinc concentrations and turnover in the rabbit uterus changed during early pregnancy. Zinc is associated with many proteins (Vallee, 1976) and its turnover may be changed by injury and wound healing (Fell et al., 1973), which have analogies with the decidualization process. Zinc concentrations are greater in the intercaruncular regions of the ovine uterus than in the caruncles, suggesting an association with the sites of secretion rather than the sites of attachment (W. A. Lane \& B. Cook, unpublished observations). Preliminary work indicates that zinc concentrations are not greatly different between anoestrus and the luteal phase of the cycle, although they increase substantially during pregnancy (W. A. Lane \& B. Cook, unpublished observations). Table 1 shows typical zinc concentrations at different sites in a uterus from a ewe carrying a single fetus at about 120 days gestation. Investigations are in progress to determine to what compounds, if any, this zinc is bound and to examine any endocrine dependence there may be in the increase in intercaruncular metal concentration.

Table 1. Zinc concentrations in the uterine tissues of one ewe at Day 120 of gestation

\begin{tabular}{lc}
\hline \multicolumn{1}{c}{ Tissue } & $\begin{array}{c}\text { Zn conc. } \\
(\mu \mathrm{g} / \mathrm{g} \text { dry wt)* }\end{array}$ \\
\hline $\begin{array}{l}\text { Non-pregnant horn } \\
\text { Caruncle } \\
\text { Intercaruncle }\end{array}$ & 71 \\
$\begin{array}{l}\text { Pregnant horn } \\
\text { Placentome } \\
\text { Cotyledon } \\
\text { Intercotyledon } \\
\text { Caruncle } \\
\text { Intercaruncle }\end{array}$ & 109 \\
& 92 \\
& 60 \\
* The coefficient of variation for the & 770 \\
assay (by atomic absorption spectro- \\
photometry) was approximately $5 \%$.
\end{tabular}

Nalbandov (1971) reviewed the current status of the relationship between oestrogen and histamine. On the basis principally of work by Ferrando \& Nalbandov (1968), he concluded that one of the functions of ovarian (follicular) oestrogen was to release histamine from uterine mast cells. The role of histamine in molecular terms remains unknown, but it is concerned with the induction of the decidual reaction and then, by implication, with implantation (in rodents, if not domestic species). Since Nalbandov's review, a few papers have been published which emphasize the interaction of oestrogen and histamine in uterine tissues. McKercher, van Orden, Bhatnager \& Burke (1973) administered oestrogen to ovariectomized rats and, using fluorometric techniques, found that histamine was lost from uterine mast cells within $1 \mathrm{~h}$. Subsequently, Brody, Edvinsson \& Sjöberg (1975) found that elimination of stainable mast cells from the uterus did not inhibit the hyperaemic response to oestrogen and that, under these conditions, uterine histamine levels were only depleted by $25 \%$. It seems possible that there was a uterine source of histamine other than mast cells. 
Brandon (1977) has shown that histamine antagonists inhibit the acute oedematous response to oestradiol in the immature rat uterus, and Brandon \& Wallis (1977) report that a combination of histamine antagonists inhibited the increase in vascular permeability which is normally found at sites of blastocyst attachment in the rat. These results were interpreted as showing that histamine may be involved in the mediation of some oestrogen- and blastocyst-dependent phenomena. These findings are consistent with the hypothesis of Schayer (1962) that histamine, formed as a result of the induction of histidine decarboxylase in or near the endothelium of small blood vessels, may act as a regulator of microcirculation. Oestrogen or some other compound produced by the blastocyst could provide the initial stimulus for the induction of this enzyme. As well as influencing the vascular bed of the uterus, histamine may also facilitate the concentration of oestrogen in the uterus (De Carli, Castro-Vázquez, Macome \& Rosner, 1971 ; Castro-Vázquez, Gómez, De Carli \& Rosner, 1976). This would provide a positive feedback loop to enhance oestrogen uptake.

This discussion of histamine effects has centred on rodents because the histamine involvement in implantation has been little studied in domestic species. Rodents may represent a special case in this context, for decidualization in rats and mice is pronounced, whereas in cows, sheep, pigs and horses it is not. Nevertheless, in the domestic animals, an increase in uterine vascularity is a characteristic of implantation sites and is probably of functional significance for the epithelio-chorial placenta; growth of the uterus during pregnancy is not likely to be independent of oestrogen uptake. The possible actions of histamine during blastocyst development should not therefore be overlooked in domestic animals.

Nalbandov (1971) asserted that "the laboratory rat is in a class by itself in that it requires estrogen for implantation in an endometrium previously prepared for implantation by the action of progesterone". McLaren (1973) observed that "the receptive state of the uterus is local in space, so that implantation can be inhibited in one part by the administration of hormones, while proceeding normally in the rest of the uterus; it is also local in time, and may be shifted by hormone treatments". The work reviewed here suggests that Nalbandov's (1971) assertion may have to be revised; species other than rats and mice may not need maternal oestrogen to ensure implantation, but, until experiments have been conducted in which embryonic steroidogenesis is blocked without checking maternal steroid production, the possibility that the blastocysts themselves produce all the oestrogen they need cannot be excluded. (Inhibitors of steroid aromatase activity exist; the technique will require treatment of the embryos but not of the mother.) The fact that blastocysts are producing steroids would accord with McLaren's (1973) statement. In the context of implantation, what more appropriate way of ensuring the correct distribution of hormones in space and time could there be than by having the blastocysts themselves contribute to the hormonal requirements of the implantation process?

We thank Dr Janet Brandon for helpful discussions and providing a preprint of her paper; Dr D. W. Bullock and Dr R. B. Heap for supplying preprints of work in press, and Dr P. J. Dziuk, Dr J. E. O'Grady and Dr Marilyn B. Renfree for help before, and Mrs Anne Kelly for help during, preparation of the manuscript. Financial support from the Ford Foundation is gratefully acknowledged.

\section{References}

Allen, W.R. \& MooR, R.M. (1972) The origin of the equine endometrial cups. I. Production of PMSG by fetal trophoblast cells. J. Reprod. Fert. 29, 313-316.

ARMSTRONG, D.T. (1968) Gonadotropins, ovarian metabolism and steroid biosynthesis. Recent Prog. Horm. Res. 24, 255-320.

Assheton, R. (1898) The development of the pig during the first ten days. Q. Jl Microsc. Sci. 41, 329-359.

BAZER, F.W. (1975) Uterine protein secretions: relationship to development of the conceptus. J. Anim. Sci. 41, 1376-1382.
Bazer, F.W., Chen, T.T., Knights, J.W., Schlosnagle, D., Baldwin, N.J. \& Roberts, R.M. (1975) Presence of a progesterone-induced, uterine specific, acid phosphatase in allantoic fluid of gilts. J. Anim. Sci. 41, 1112-1119.

ВеАто, M. (1977) Hormonal control of uteroglobin biosynthesis. In Development in Mammals, Vol. 1, pp. 361-384. Ed. M. H. Johnson. North Holland, Amsterdam.

BeIER, H. M. (1974) Oviducal and uterine fluids. $J$. Reprod. Fert. 37, 221-237.

Downloaded from Bioscientifica.com at 04/26/2023 01:54:46AM via free access 
BEIER, H.M. (1976) Uteroglobin and related biochemical changes in the reproductive tract during early pregnancy in the rabbit. J. Reprod. Fert., Suppl. 25, $53-69$.

Bergström, S. (1967) Prostaglandins: members of a new hormonal system. Science, N.Y. 157, 382-391.

BetTERJdGe, K.J. (1977) Embryo Transfer in Farm Animals: A Review. Canada Dept. Agric. Monograph 16, Ottawa.

Blandau, R.J. (Ed.) (1971) The Biology of the Blastocyst. University of Chicago Press.

BoshieR, D.P. (1969) A histological and histochemical examination of implantation and early placentome formation in sheep. J. Reprod. Fert. 19, 51-61.

BöviNG, B.G. (1971) Biomechanics of implantation. In The Biology of the Blastocyst, pp. 423-442. Ed. R. J. Blandau. University of Chicago Press.

BRANDON, J.M. (1977) Inhibition of the acute oedematous response to oestradiol in the immature rat uterus by administration of a combination of mepyramine, a histamine $\mathrm{H}_{1}$ - and burimamide, a histamine $\mathrm{H}_{2}$-receptor antagonist. J. Endocr. 73, $42 P-43 P$.

Brandon, J.M. \& Wallis, R.M. (1977) Effect of mepyramine, a histamine $\mathrm{H}_{1}-$, and burimamide, a histamine $\mathbf{H}_{2}$-receptor antagonist, on ovum implantation in the rat. J. Reprod. Fert. 50, 251-254.

Brody, M.J., Edvinsson, L. \& Sü̈BERG, N.-O. (1975) Preservation of estrogen-induced increase of uterine blood volume following catecholamine and mast cell histamine depletion. Proc. Soc. exp. Biol. Med. 149, 120-123.

Bullock, D.W. (1977a) Steroids from the pre-implantation blastocyst. In Development in Mammals, Vol. 2, pp. 199-208. Ed. M. H. Johnson. North Holland, Amsterdam.

Bullock, D.W. (1977b) In vitro translation of messenger RNA for a uteroglobin-like protein from rabbit lung. Biol. Reprod. 17, 104-107.

Bullock, D.W., Woo, S.L.C. \& O'Malley, B.W. (1976) Uteroglobin messenger RNA: translation in vitro. Biol. Reprod. 15, 435-443.

Burdick, H.O. \& Pincus, G. (1935) The effect of oestrin injections upon the developing ova of mice and rabbits. Am. J. Physiol. 111, 201-208.

Buttle, H.L., Forsyth, I.A. \& KNAGgs, G.S. (1972) Plasma prolactin measured by radioimmunoassay and bioassay in pregnant and lactating goats and the occurrence of a placental lactogen. J. Endocr. 53, 483-491.

Castro-Vázquez, A., Gómez, E., De Carli, D.N. \& RosNer, J.M. (1976) Further evidence for histamine facilitating oestrogen action in the uterus. J. Endocr. 68, 121-126.

Cerini, M., Cerini, J.C., Findlay, J.K. \& Lawson, R.A.S. (1976) Preliminary characterization of pregnancy specific antigen(s) in the ewe. J. Reprod. Fert. 46, 534, Abstr.

Cerini, M., Findlay, J.K. \& Lawson, R.A.S. (1976) Pregnancy-specific antigens in the sheep: application to the diagnosis of pregnancy. $J$. Reprod. Fert. 46, 65-69.

Chakraborty, P.K., England, D.C. \& Stormshak, F. (1972) Effect of $17 \beta$-estradiol on pituitary gonado- tropins and luteal function in gilts. J. Anim. Sci. 34, 427-429.

Chan, J.S.D., Robertson, H.A. \& Friesen, H.G. (1976) The purification and characterization of ovine placental lactogen. Endocrinology 98, 65-76.

Chang, M.C. (1950) Development and fate of transferred rabbit ova or blastocysts in relation to the ovulation time of recipients. $J$. exp. Zool. 114, 197216.

ChANG, M.C. (1952) Development of bovine blastocyst, with a note on implantation. Anat. Rec. 113, 143162.

ChANG, M.C. (1966) Effects of oral administration of medroxyprogesterone acetate and ethinyl estradiol on the transportation and development of rabbit eggs. Endocrinology 79, 939-948.

ChanG, M.C. \& Rowson, L.E.A. (1965) Fertilization and early development of Dorset Horn sheep in the spring and summer. Anat. Rec. 152, 303-316.

COOK, B. \& TAYLOR, P.D. (1974) Estrogen binding in ovine corpora lutea. Proc. 7th A. Meeting, Soc. Study of Reproduction, Ottawa, p. 64, Abstr.

Cook, B., Niswender, G.D., SutTerlin, N.S., Norton, H.W. \& Nalbandov, A.V. (1968) The influence of some steroids, including estrogens, on progesterone synthesis in vitro by porcine corpora lutea. Steroids 11, 321-336.

Cook, B., Karsch, F. J., Foster, D. L. \& Nalbandov, A.V., (1974) Estrogen-induced luteolysis in the ewe: possible sites of action. Endocrinology 94, 11971201.

Corner, G.W. (1921) Internal migration of the ovum. Bull. Johns Hopkins Hosp. 32, 78-83.

Crombie, P.R. (1970) Ultrastructure of the foetalmaternal attachment in the pig. J. Physiol., Lond. 210, $101 P$.

DANIEL, J.C., JR (1976) Blastokinin and analogous proteins. J. Reprod. Fert., Suppl. 25, 71-83.

De Carli, D.N., Castro-Vázquez, A., Macome, J.C. \& ROSNER, J.M. (1971) Effect of histamine on the uterine uptake of oestradiol. $J$. Endocr. 50, 541542.

Denamur, R., Martinet, J. \& Short, R.V. (1973) Pituitary control of the ovine corpus luteum. $J$. Reprod. Fert. 32, 207-220.

Dhindsa, D.S., DziUk, P.J. \& Norton, H.W. (1967) Time of transuterine migration and distribution of embryos in the pig. Anat. Rec. 159, 325-330.

DickmanN, Z., DeY, S.K. \& Sen GuPTA, J. (1976) A new concept: control of early pregnancy by steroid hormones originating in the pre-implantation embryo. Vitams Horm. 34, 215-242.

DU Mesnil DU Buisson, F. \& Denamur, R. (1968) Mécanismes du controle de la fonction lutéal chez la truie, la brebis et la vache. In Progress in Endocrinology, pp. 927-934. Ed. C. Gual. Excerpta Medica, Int. Congr. Ser. No. 184, Amsterdam.

Dziuk, P.J., Polge, C. \& Rowson, L.E. (1964) Intrauterine migration and mixing of embryos in swine following egg transfer. J. Anim. Sci. 23, 37-42.

Fell, G.S., Fleck, A., Cuthbertson, D.P., Queen, K., Morrison, C., Bessent, R.G. \& Husain, S.L. (1973) Urinary zinc levels as an indication of muscle catabolism. Lancet i, 280-282. 
Ferrando, G. \& Nalbandov, A.V. (1968) Relative importance of histamine and estrogen on implantation in rats. Endocrinology 83, 933-937.

Finn, C.A. (1971) The biology of decidual cells. Adv. Rep. Physiol. 5, 1-26.

Flood, P.F. \& Marrable, A.W. (1975) A histochemical study of steroid metabolism in the equine fetus and placenta. J. Reprod. Fert., Suppl. 23, 569-573.

Gadsby, J.E., Burton, R.D., Heap, R.B. \& Perry, J.S. (1976) Steroid metabolism and synthesis in early embryonic tissue of pig, sheep and cow. $J$. Endocr. 71, 45P-46P.

Gardner, M.L., First, N.L. \& Casida, L.E. (1963) Effect of exogenous estrogens on corpus luteum maintenance in gilts. J. Anim. Sci. 22, 132-134.

GodiNG, J.R. (1974) The demonstration that $\mathrm{PGF}_{2 \alpha}$ is the uterine luteolysin in the ewe. J. Reprod. Fert. 38, 261-271.

Goldenterg, R.L., Bridson, W.E. \& Kohler, P.O. (1972) Estrogen stimulation of progesterone synthesis by porcine granulosa cells in culture. Biochem. Biophys. Res. Comm. 48, $101-107$.

GreEN, W.W.\& WINTERS, L.M. (1945) Prenatal development of the sheep. Tech. Bull. Minn. agric. Exp. Stn No. 169.

Green, W.W. \& Winters, L.M. (1946) Cleavage and attachment stages of the pig. J. Morph. 78, 305-315.

Greenwald, G.S. (1959) The comparative effectiveness of estrogens in interrupting pregnancy in the rabbit. Fert. Steril. 10, 155-161.

Hansson, V., Weddington, S.C., MClean, W.S., Smith, A.A., NAYFeH, S.N., French, F.S. \& RitzéN, E.M. (1975) Regulation of seminiferous tubular function by FSH and androgen. $J$. Reprod. Fert. 44, 363-375.

Harrison, F.A., Heap, R.B., Horton, E.W. \& Poyser, N.L. (1972) Identification of prostaglandin $F_{2 \alpha}$ in uterine fluid from the non-pregnant sheep with an autotransplanted ovary. J. Endocr. 53, 215-222.

Heap, R.B., Perry, J.S., Burton, R.D., Gadsby, J.E., WyatT, C. \& Jenkin, G. (1977) Blastocyst steroidogenesis and embryo-maternal interactions in the establishment of pregnancy. In Reproduction and Evolution, pp. 341-347. Eds J. H. Calaby \& C. H. Tyndale-Biscoe. Australian Academy of Science, Canberra.

Heuser, C.H. \& Streeter, G.L. (1929) Early stages in the development of pig embryos. Contrib. Embryol. Carneg. Instn 20, 1-30.

Huff, R.L. \& Eik-Nes, K.B. (1966) Metabolism in vitro of acetate and certain steroids by six-day-old rabbit blastocysts. J. Reprod. Fert. 11, 57-63.

HuNTER, R.H.F. (1976) Reproductive physiology in the bovine female: a review. In Beef Cattle Production in Developing Countries, pp. 79-104. Ed. A. J. Smith. University of Edinburgh.

HuNTER, R.H.F. (1977a) Function and malfunction of the Fallopian tubes in relation to gametes, embryos and hormones. Eur. J. Obstet. Gynec. Reprod. Biol. 7, 267-283.

Hunter, R.H.F. (1977b) Physiological factors influencing ovulation, fertilization, early embryonic development and establishment of pregnancy in pigs. Br. vet. J. 133, 461-470.

Hunter, R.H.F., CoOK, B. \& BAKer, T.G. (1976)
Dissociation of response to injected gonadotropin between the Graafian follicle and oocyte in pigs. Nature, Lond. 260, 156-158.

Karsch, F.J., Roche, J.F., Noveroske, J.W., Foster, D.L., Norton, H.W. \& Nalbandov, A.V. (1971) Prolonged maintenance of the corpus luteum of the ewe by continuous infusion of luteinizing hormone. Biol. Reprod. 4, 129-136.

Kimball, F.A. \& Hansel, W. (1974) Estrogen cytosol binding proteins in bovine endometrium and corpus luteum. Biol. Reprod. 11, 566-577.

LASTER, D.B. (1977) A pregnancy-specific protein in the bovine uterus. Biol. Reprod. 16, 682-690.

LeE, C., Keyes, P.L. \& Jacobson, H.I. (1971) Estrogen receptor in the rabbit corpus luteum. Science, N.Y. 173, 1032-1033.

Louis, T.M., PARry, D.M., Robinson, J.S., ThORbURN, G.D. \& Challis, J.R.G. (1977) Effects of exogenous progesterone and oestradiol on prostaglandin $F$ and 13,14-dihydro-15-oxo prostaglandin $F_{2 x}$ concentrations in uteri and plasma of ovariectomized ewes. J. Endocr. 73, 427-439.

Lutwak-ManN, C. \& McInTosh, J.E.A. (1969) Zinc and carbonic anhydrase in the rabbit uterus. Nature Lond. 221, 1111-1114.

MARSH, J.M. (1976) The role of cyclic AMP in gonadal steroidogenesis. Biol. Reprod. 14, 30-53.

Martal, J. \& DJiAne, J. (1977) The production of chorionic somatomammotrophin in sheep. $J$. Reprod. Fert. 49, 285-289.

Martensz, N.D., Baird, D.T., Scaramuzzi, R.J. \& VAN LooK, P.F.A. (1976) Androstenedione and the control of luteinizing hormone in the ewe during anoestrus. J. Endocr. 69, 227-237.

McIntosh, J.E.A. \& Lutwak-ManN, C. (1972) Zn transport in rabbit tissues. Some hormonal aspects of the turnover of $\mathrm{Zn}$ in female reproductive organs, liver and body fluids. Biochem. $J$. 126, 869-876.

MCKerCher, T.C., VAN Orden, L.S., BhatNager, R.K. \& BURKE, J.P. (1973) Estrogen-induced biogenic amine reduction in rat uterus. J. Pharmac. exp. Ther. 185, 514-522.

McLaren, A. (1972) The embryo. In Reproduction in Mammals, Book 2, pp. 1-42. Eds C. R. Austin \& R. V. Short. Cambridge University Press.

MCLAREN, A. (1973) Endocrinology of implantation. J. Reprod. Fert., Suppl. 18, 159-166.

MCNatTy, K.P., SAWERS, R.S. \& MCNeilly, A.S. (1974) A possible role for prolactin in control of steroid secretion by the human Graafian follicle. Nature, New Biol. 250, 653-655.

Moor, R.M. \& Rowson, L.E.A. (1964) Influence of the embryo and uterus on luteal function in the sheep. Nature, Lond. 201, 522-523.

Moor, R.M., Allen, W.R. \& Hamilton, D.W. (1975) Origin and histogenesis of equine endometrial cups. J. Reprod. Fert., Suppl. 23, 391-396.

Naftolin, F., Ryan, K.J., Davies, I.J., RedDY, V.V., Flores, F., Petro, Z., Kuhn, M., White, R.J., TAKAOKA, Y. \& Wolin, L. (1975) The formation of estrogens by central neuroendocrine tissues. Recent Prog. Horm. Res, 31, 295-319.

Nalbandov, A.V. (1971) Endocrine control of implantation In The Biology of the Blastocyst, pp. 383-392. Ed. R. J. Blandau, Bniversity of Chielagot Press. $6 / 2023$ 01:54:46AM via free access 
Niswender, G.D., Roche, J.F., Foster, D.L. \& MIDGely, A.R. (1968) Radioimmunoassay of serum levels of luteinizing hormone during the cycle and early pregnancy in ewes. Proc. Soc. exp. Biol. Med. 129, 901-904.

Noyes, R.W. \& Dickmann, Z. (1960) Relationship of ovular age to endometrial development. J. Reprod. Fert. 1, 186-196.

PatTle, R.E. (1975) The lung surfactant; an introduction. J. Reprod. Fert., Suppl. 23, 645-650.

Perry, J.S. \& Rowlands, I.W. (1962) Early pregnancy in the pig. J. Reprod. Fert. 4, 175-188.

Perry, J.S., Heap, R.B., Burton, R.D. \& Gadsby, J.E. (1976) Endocrinology of the blastocyst and its role in the establishment of pregnancy. J. Reprod. Fert., Suppl. 25, 85-104.

Polge, C. \& Dziuk, P.J. (1970) Time of cessation of intrauterine migration of pig embryos. J. Anim. Sci. 31, 565-566.

PsychоуоS, A. (1973) Endocrine control of egg implantation. In Handbook of Physiology, Section 7, Endocrinology, 2, Female Reproduction System, Part 2, pp. 187-215, Eds R. O. Greep \& E. B. Astwood. Am. Physiol. Soc., Washington D.C.

Reimers, T.J., Dziuk, P.J., Bahr, J., Sprecher, D.J., Webel, S.K. \& HARMON, B.G. (1973) Transuterine embryonal migration in sheep, anterioposterior orientation of pig and sheep fetuses and presentation of pigiets at birth. J. Anim. Sci. 37, 1212-1217.

REYNoLDS, E.O.R. (1973) Physiological effects of reduction in lung surfactant. Proc. R. Soc. Med. 66, 388-389.

Richards, J.S. \& Midgley, A.R., Jr (1976) Protein hormone action: a key to understanding ovarian follicular and luteal cell development. Biol. Reprod. 14, 82-94.

Richards, J.S. \& Williams, J.J. (1976) Luteal cell receptor content for prolactin (PRL) and luteinizing hormone (LH): regulation by LH and PRL. Endocrinology 99, 1571-1581.

ROBERTS, G.P. \& PARKER, J.M. (1974) Macromolecular components of the luminal fluid from the bovine uterus. J. Reprod. Fert. 40, 291-303.

Robertson, H.A., KING, G.J. \& DyCK, G.W. (1978) The appearance of oestrone sulphate in the peripheral plasma of the pig early in pregnancy. J. Reprod. Fert. 52, 337-338.

Rowson, L.E.A. (1971) The role of reproductive research in animal production. J. Reprod. Fert. 26, 113-126.

Rowson, L.E.A. \& MooR, R.M. (1966a) Embryo transfer in the sheep: the significance of synchronis- ing oestrus in the donor and recipient animal. J. Reprod. Fert. 11, 207-212.

Rowson, L.E.A. \& Moor, R.M. (1966b) Development of the sheep conceptus during the first fourteen days. J. Anat. 100, 777-785.

Rowson, L.E.A. \& MooR, R.M. (1967) The influence of embryonic tissue homogenate infused into the uterus, on the life span of the corpus luteum of the sheep. J. Reprod. Fert. 13, 511-516.

Rowson, L.E.A., MOoR, R.M. \& Lawson, R.A.S. (1969) Fertility following egg transfer in the cow: effect of method, medium and synchronization of oestrus. J. Reprod. Fert. 18, 517-523.

Sayena, B.B., Hassan, S.H., Haour, F. \& SchmidtGollwitzer, M. (1974) Radioreceptor assay of human chorionic gonadotropin: detection of early pregnancy. Science, N.Y. 184, 793-795.

SCANLON, P.F. (1972) Frequency of transuterine migration of embryos in ewes and cows. J. Anim. Sci. 34, 791-794.

SCHAYER, R.W. (1962) Evidence that induced histamine is an intrinsic regulator of the microcirculatory system. Am.J. Physiol. 202, 66-72.

SCOTt, R.S. \& ReNNIE, P.I.C. (1971) An estrogen receptor in the corpora lutea of the pseudopregnant rabbit. Endocrinology 89, 297-301.

Singer, W., Desjardins, P. \& Friesen, H.G. (1970) Human placental lactogen. An index of placental function. Obstet. Gynec., N.Y. 36, 222-232.

THIBAULT, C. (1972) Physiology and physiopathology of the Fallopian tube. Int. J. Fert. 17, 1-13.

van Niekerk, C.H. \& Allen, W.R. (1975) Early embryonic development in the horse. J. Reprod. Fert., Suppl. 23, 495-498.

van Niekerk, C.H. \& Gerneke, W.H. (1966) Persistence and parthenogenetic cleavage of tubal ova in the mare. Onderstepoort J. vet. Res. 33, 195-231.

van Niekerk, C.H., Morgenthal, J.C. \& Gerneke, W.H. (1975) Relationship between the morphology of and progesterone production by the corpus luteum of the mare. J. Reprod. Fert., Suppl. 23, 171-175.

VALLEE, B.L. (1976) Zinc biochemistry: a perspective. Trends biochem. Sci. 1, 88-91.

WARWICK, B.L. (1926) Intra-uterine migration of ova in the sow. Anat. Rec. 33, 29-33.

WimsATT, W.A. (1975) Some comparative aspects of implantation. Biol. Reprod. 12, 1-40.

Winters, L.M., Green, W.W. \& Comstock, R.E. (1942) Prenatal development of the bovine. Tech. Bull. Minn. agric. Exp. Stn No. 151. 